\title{
KAJIAN PENGGUNAAN CAPTOPRIL DAN RAMIPRIL TERHADAP PARAMETER FUNGSI GINJAL PADA PASIEN CHF
}

\author{
Asniar Pascayantri ${ }^{1}$, Elly Wahyudin ${ }^{2}$ dan Hasyim Kasim ${ }^{2}$ \\ ${ }^{1}$ Fakultas Farmasi, Universitas Hasanuddin, Makassar \\ ${ }^{2}$ Fakultas Kedokteran, Universitas Hasanuddin, Makassar
}

Kata Kunci :

Inhibitor ACE, Captopril, Ramipril, Gagal Jantung Kongestif, Ureum, Serum Kreatinin
Masuk 25-12-2018

Revisi 27-12-2018

Diterima 27-12-2018

\section{Korespondensi}

\section{Elly Wahyudin}

ellywahyudins@gmail.com

Copyright

(C) 2018 Majalah Farmasi Farmakologi Fakultas

Farmasi - Makassar

Diterbitkan tanggal 31-12-2018

Dapat Diakses Daring Pada:

http://journal.unhas.ac.id /index.php/mff

\section{ABSTRAK}

Penelitian ini bertujuan untuk mengkaji penggunaan inhibitor ACE (Angiotensin Converting Enzyme) yaitu captopril dan ramipril pada pasien CHF berdasarkan outcome terhadap parameter fungsi ginjal di bagian PJT (Pusat Jantung Terpadu) RSUP Dr. Wahidin Sudirohusodo Makassar. Penelitian ini bertujuan untuk mengetahui efek perubahan inhibitor ACE terhadap parameter fungsi ginjal yang terjadi pada pasien CHF. Desain penelitian yang digunakan adalah penelitian observasional non eksperimen dengan rancangan deskriptif-analitik, yang mencapai jumlah 40 orang sampel. Data yang dianalisis secara deskriptif dan statistik berupa parameter fungsi ginjal. Hasil penelitian menunjukkan bahwa pasien yang menggunakan inhibitor ACE kerja singkat yaitu captopril (6,25mg/8jam) adalah 20 orang (50\%) dan yang mengunakan inhibitor kerja lama yaitu ramipril $(5 \mathrm{mg} / 24 \mathrm{jam})$ sebanyak 20 orang (50\%). Data parameter fungsi ginjal dianalisis dengan menggunakan SPSS 23 melalui tes distribusi normalitas dengan menggunakan uji Normality Kolmogorov-Smirnov yang diikuti dengan uji t-tes sampel berpasangan dan uji Multivariate One Way ANOVA. Hasil menunjukkan adanya perbedaan nilai sebelum dan sesudah terapi. Kejadian peningkatan fungsi ginjal lebih besar pada data serum kreatinin $p<0,05$ dibandingkan pada data ureum $\mathrm{p}>0,05$ pada kedua kelompok terapi..

\section{PENDAHULUAN}

CHF (congestive heart failure atau gagal jantung kongestif) merupakan salah satu masalah kesehatan dalam sistem kardiovaskular yang angka kejadiannya terus meningkat. Menurut data DepartemenKesehatan (2012), penderita CHF di Indonesia merupakanpenderita yang paling sering menjalani rawat inap di rumah sakit. Selain itu, penyakit yang paling sering memerlukan perawatan ulang di rumah sakit adalah gagal jantung (readmission), walaupun pengobatan dengan rawat jalan telah diberikan secara optimal. Resiko kematian yang diakibatkan oleh CHF adalah sekitar 5-10\% per tahun pada kasus gagal jantung ringan dan meningkat menjadi 30 $40 \%$ pada gagal jantung berat (1).

Efek kardioprotektif dari penggunaan inhibitor ACE (angiotensin converting enzyme) telah banyak menunjukkan efek menguntungkan pada beberapa penelitian dan menjadi rekomendasil ini pertama terapifarmakologi pada pasien CHF yang ditujukan untuk mengurangi peningkatan afterload dan overload (2). American College of Cardiology/American Heart Association (ACC/AHA) tahun 2009 dan Pedoman Konsensus Kanad atahun 2006 sangat merekomendasikan penggunaan ihibitor ACE pada pasien gagal jantung dengan penurunan fraksi ejeksi ventrikel kiri (LVEF) $<40 \%$ untuk mengurangi remodeling jantung (3). Namun beberapa jurnal menyebutkan adanya penurunan fungsi ginjal terhadap penggunanaan inhibitor ACE yang ditandai dengan kenaikan kreatinin serum pada pasien $\mathrm{CHF}$ yang kemungkinan dimediasi oleh adanya efek antagonisme dari angiotensin II yang memediasi konstriksi pada bagian arteriol efferent $(4,5)$.

\section{METODE PENELITIAN}

\section{Rancangan Penelitian}

Jenis penelitian ini adalah penelitian observasional non eksperimen dengan rancangan deskriptif analitik serta metode pengambilan data secara retrospektif.

Variabel independen adalah inhibitor ACE, yaitu inhibitor ACE kerja singkat (tablet captopril dengan dosis $6,25 \mathrm{mg} / 8 \mathrm{jam}$ ) dan inhibitor ACE kerja lama (tablet ramipril dengan dosis $5 \mathrm{mg} / 24 \mathrm{jam}$ ). Variabel dependen adalah parameter fungsi ginjal yaitu kadar ureum dan kreatinin serum.

\section{Populasi dan Sampel Penelitian}

Populasi penelitian adalah semua pasien dengan diagnosa $\mathrm{CHF}$ dan hasil pemeriksaan ekokardiogram fraksi ejeksi $<40 \%$ pada bagian PJT (Pusat Jantung Terpadu) di RSUP Dr. Wahidin Sudirohusodo, Makassar periode bulan Agustus hingga Desember 2017 yang mendapatkan terapi inhibitor ACE yaitu tablet captopril 6,25 mg/8 jam dan tablet ramipril $5 \mathrm{mg} / 24$. Sampel penelitian adalah pasien yang berusia 20-80 tahun dengan pemeriksaan parameter fungsi ginjal yaitu kadar serum kreatinin selama 1 bulan.

\section{Pengambilan dan Pengolahan Data Penelitian}

Data hasil pengukuran parameter fungsi ginjal berupa data ureum dan kreatinin serum selama 1 bulan di laboratorium PJT RSUP Dr. Wahidin Sudirohusodo. Data profil pengobatan dan data 
klinis pasien dikumpulkan untuk keperluan analisis data yang diperoleh dari data rekam medik dan hasil pemeriksaan laboratorium berupa data ureum dan serum kreatinin. Analisis statistik dilakukan untuk melihat perubahan yang terjadi terhadap parameter fungsi ginjal berupa data ureum dan serum kreatinin terhadap kelompok terapi yang diteliti yaitu kelompok captopril dan kelompok ramipril.

\section{HASIL DAN PEMBAHASAN}

Pengumpulan sampel dilakukan selama periode bulan periode bulan Agustus 2017 hingga Desember 2017 di bagian PJT (Pusat Jantung Terpadu) RSUP. Dr. Wahidin Sudirohusodo Makassar. Subjek penelitian yang memenuhi kriteria inklusi dan eksklusi berjumlah 40 orang pasien yang didiagnosa $\mathrm{CHF}$ dan menggunakan inhibitorAngiotensin Converting Enzyme (ACE), 20 orang menggunakan captopril dengan dosis $6,25 \mathrm{mg} / 8$ jam PO dan 20 orang menggunakan ramipril dengan dosis $5 \mathrm{mg} / 24$ jam PO. Penelitian dilakukan sesuai prosedur penelitian serta berdasarkan ketentuan dan syarat yang berlaku di lokasi penelitian. Jenis data penelitian yang dikumpulkan meliputi data pemeriksaan ureum dan serum kreatinin dari tiap kelompok terapi yang akan diteliti, yaitu kelompok captoril $(6,25 \mathrm{mg} / 8$ jam PO) dan kelompok ramipril ( $5 \mathrm{mg} / 24$ jam PO. Berdasarkan hasil analisis statistik dengan menggunakan uji Normality Kolmogrov-Smirnov dan dilanjutkan dengan uji Paired t-test sample menunjukkan adanya perubahan yang terjadi baik pada data ureum dan serum kreatinin dari kedua kelompok terapi. Hasil analisis statistik Multivariate One Way ANOVA menunjukkan data perubahan serum kreatinin yang signifikan $(\mathrm{p}<0,05)$ dari kedua kelompok terapi dibandingkan data ureum $(p>0,05)$ dari kedua kelompok terapi. Hal ini sesuai pada penelitian yang dilakukan sebelumnya, bahwa kadar serum kreatinin berada dalam keadaan relatif konstan sehingga menjadikannya sebagai penanda filtrasi ginjal yang baik dan juga digunakan dalam menentukan e-GFR atau perkiraan laju filtrasi glomerulus $(6,7,8,9)$.

Inhibitor ACE merupakan salah satu golongan obat yang dapat mengubah hemodinamika intraglomerular yang mengganggu kemampuan ginjal untuk meregulasi tekanan glomerular secara, terjadi penurunan tekanan, dan mengakibatkan dose-dependent vasoconstriction pada arteriola aferen. Selain itu metabolit aktif maupun non aktif dari inhibitor ACE seluruhnya diekskresikan melalui ginjal. Ginjal juga menerima 25\% dari output jantung (CO) dalam keadaan normal untuk mengeliminasi produk buangan, toksin dan obat dari tubuh. Pada kasus pasien CHF terjadi penurunan output jantung, sehingga menyebabkan penurunan fungsi ginjal dari setiap bagian fungsi ginjal termasuk klirens obat dan metabolitnya (4).

Pada perawatan primer rutin, kebanyakan pasien yang memulai pengobatan dengan inhibitor ACE hanya memiliki sedikit perubahan fungsi ginjal. Namun, peningkatan konsentrasi kreatinin lebih dari 10\% setelah memulai pengobatan inhibitor ACE mempengaruhi lebih dari 15\% pasien dan memiliki implikasi penting. Peningkatan kreatinin yang ditunjukkan setelah dimulainya pengobatan inibitor ACE dikaitkan dengan risiko kardiorenal (4).

Rekomendasi dalam berbagai panduan internasional untuk menghentikan pengobatan inhibitor ACE hanya jika kreatinin meningkat $30 \%$ atau lebih setelah inisiasi ditandai dengan peningkatan serum kreatinin lebih dari $>0,5 \mathrm{mg} / \mathrm{dL}$ jika serum kreatinin sebelumnya $<2 \mathrm{mg} / \mathrm{dL}$ atau peningkatan $>1$ $\mathrm{mg} / \mathrm{dL}$ jika kreatinin serum sebelumnya adalah $>2 \mathrm{mg} / \mathrm{dL}$ (5), dan jika disertai dengan peningkatan kalium serum 5,5sampai $6 \mathrm{mmol} / \mathrm{L}$, dimana pemeriksaan kadar kalium diperlukan minimal 3 hari sampai 2 minggu setelah pemberian dosis awal atau setelah dosis dinaikkan (8), namun sejauh ini tidak ada tanda-tanda hiperkalemia ataupun peningkatan kadar kalium dalam penelitian ini serta tidak adanya penghentian penggunaan terapi pada penelitian ini.

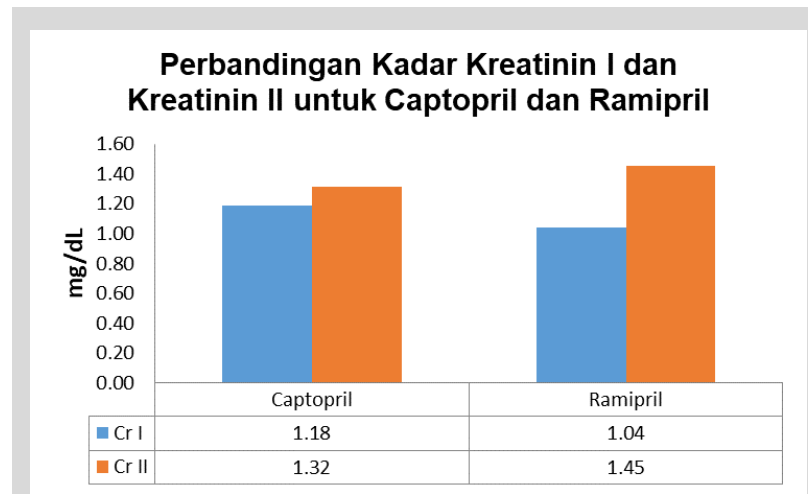

Gambar 1. Perbandingan rata-rata kadar kreatinin sebelum dan sesudah penggunaan obat captopril $(6,25 \mathrm{mg} / 8 \mathrm{jam} \mathrm{PO})$ dan ramipril $(5 \mathrm{mg} / 24 \mathrm{jam} \mathrm{PO}$ ) berdasarkan hasil analisis statistik paired sample ttest

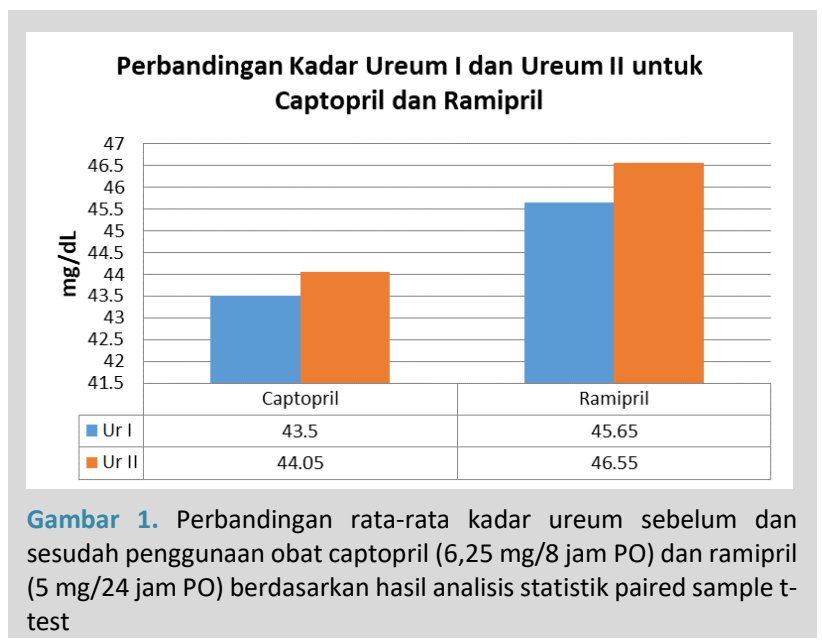

\section{KESIMPULAN}

Hasil uji statistik menggunakan uji normalitas distribusi dengan Test of Normality Kolmogorov-Smirnov yang dilanjutkan dengan uji statistika t-test berpasangan (Paired sample t-test) menunjukkan data serum kreatinin menunjukkan perubahan yang signifikan $(\mathrm{p}<0,05)$ baik pada kelompok captopril dan ramipril.

\section{DAFTAR PUSTAKA}

1. Departemen Kesehatan Republik Indonesia. Profil Kesehatan Indonesia. Jakarta: Depkes RI. 2012.

2. Yancy, Jessup, Bozkurt, Butler, Casey, Drazner. American Heart Association Heart Failure/ACCF Guideline.Circulation Heart. 2013.

3. Chua, Ignaszweski, Schwenger. Angiotensin-convertingenzyme inhibitors: An ACE in the hole for everyone. Biomedical Journal. 2011; vol 53(5):220-223

4. Schmidt, Kathryn, Krishnan, Dorothea, Henrik, Liam, Laurie. Adherence To Guidelines for Creatinine And Potassium Monitoring And Discontinuation Following Renin-Angiotensin System Blockade: A UK General Practice-Based Cohort Study. British. 2017;vol367:755-757

5. Jackevicius, Joyce, Irina, Manyee, Freny. Rates and Predictors of ACE Inhibitor Discontinuation Subsequent To Elevated Serum Creatinine: A Rstrospective Cohort Study. British Medical Journal. 2014;vol 361:305307

6. Ettehad, Emdin, Kiran, Anderson, Callender, Emberson, Chalmers, Rodgers, Rahimi. Blood pressure lowering for prevention of cardiovascular disease and death: a systematic review and meta-analysis. Lancet. 2016;vol 387:957-967

7. Ruilope, Kosiborod. Optimising Renin-Angiotensin-Aldosterone System Inhibitor Therapy In Heart Failure And Resistant Hypertension: Challenges And Solutions. EMJ. 2016;1[4]:19-26

8. Bandak, Yingying, Alessandro, Alex, Shoshana, Marie, Johan, Lars, Lesley, Josef. Hyperkalemia after iniatiating renin-angiotensin system blockade; 
The Stockholm Creatinine Measurements (SCREAM) Project. Journal of The American Heart Association. 2017;vol 377:567-568
9. Blankstein, Bakris. Changes in Kidney Function Following Heart Failure Treatment: Focus on Renin-Angiotensin System Blockade. Heart Failure Clin 4. 2011. 